\title{
'Whether or Not the Law Relating to Modern Trustees' Power and Duties have Achieved a Balance between Managing the Trust Assets and Protecting the Interest of the Beneficiaries: A Critical Analysis'
}

\author{
Md. Saifur Rahman Chowdhury \\ Advocate, Chittagong District Bar Association, Bangladesh \& Legal Expert \\ Email: saifurremedy@yahoo.com
}

Doi:10.5901/mjss.2015.v6n2p386

Abstract

The purpose of this article is to critically analyse with the reference of appropriate authority whether or not the law relating to modern trustees' power and duties have achieved a balance between managing the trust assets and protecting the interest of the beneficiaries. The duties, power and responsibilities of trustees are normally set out in the trust documents, at least in part. In this regard the range of underpinning statutory provisions contained, in particular, in the Trustee Acts 1925 and 2000 and the Trusts of Land and Appointment of Trustees Act 1996. However there is a common law standard of duty expected of trustees and that it has been modified under s 1(1) of the Trustee Act 2000 in a range of situations. As we know fiduciary obligations are particular - and peculiar -obligations recognized by equity. In certain circumstances, typically in trusts but also in agency and other relationships, equity will require one party to the relationship, called the 'fiduciary', to act in the best interests of the other, called the 'principal'. Failure to do so will mean that the first party commits the equitable wrong of breach of fiduciary duty vis-àvis the second. In the case of a typical trust, the trustee is a fiduciary who must act in the best interests of his principals, the beneficiaries. I am of the opinion that, the law relating to modern trustees' power and duties have achieved a balance sufficiently between managing the trust assets and protecting the interest of the beneficiaries. For the purpose of this research doctrinal research method has been applied. The doctrinal research method was more appropriate to apply primary and secondary data in this research.

Keywords: Trust, Trustee, Beneficiaries, Duties and Power, Responsibilities, Interest, Balance.

\section{Introduction}

According to Oxford Dictionary of Law a trustee has been defined as 'a person having a nominal title to property that he holds for the benefit of one or more others, the beneficiaries' (Oxford Dictionary of Law, p.510). It is essential for a trust to have trustees. They hold and safeguard the trust property and have complex duties to perform. It can be seen that various duties are imposed by law and/or the terms of the trust on the trustee in relation to the trust property and to the beneficiaries. In addition the trustee, as a fiduciary, has fiduciary duties. Furthermore, various powers are also conferred on the trustee. The Trustee Act 1925 and Trustee Act 2000 are the foremost relevant statutory sources in the context of trustees' power and duties, and the protection of interest of beneficiaries. Trusts of Land and Appointment of Trustees Act 1996 sometimes are relevant in the same context.

\section{Trustees' Power, Duties and Responsibilities under Common Law and Old Statutes:}

In administering the trust the laws have imposed various complex duties and responsibilities on the trustees and at the same time the trustees are given wider range of power by the various instrument of trust law. In Luke $v$ South Kensington Hotel Co (1879) 11 Ch D 121, the court held that in administering trust, the trustees must act unanimously unless the trust instrument allows otherwise. Beside the statutory duties the trustees have common law duties. The trustees owed duty of care to their beneficiary (Learoyd v Whitely [1886] LR 33 ChD 347; Bartlett v Barclays Bank Trust Company Limited [1980] Ch 515). In addition, the trustees have fiduciary duties towards the beneficiary (Bristol and West Building Society v Mathew [1998] EWCA Civ 533). In Bristol and West Building Society v Mathew [1998] EWCA Civ 533, Millet LJ described the term of fiduciary relationship as: "a fiduciary is someone who has undertaken to act for or on behalf of another in a particular matter in circumstances which give rise to a relationship of trust and confidence. The distinguishing obligation of fiduciary is the obligation of loyalty" (Moffat, G., Bean, G., and Probert, R., 2009, p.421). 
Essentially, the fiduciary duties are mainly derived from case laws. The fiduciary duty means that trustees must not make a profit from their trustee position (Bary $v$ Ford [1896] AC 44), must not buy trust property, must not use knowledge that they gain from their position for personal advantage (Buttle $v$ Sunders [1950] 2 All ER 193), and generally must promote the interest of the beneficiaries above their own interest (Clements, $R$ and Abass, A., 2011, p.450). The fiduciary duties are strictly enforced by the courts (Imageview Management $v$ Jack [2009] 2 All ER 666). The statutory provisions inaugurated to extend the power and duties of the trustees in relation to managing the trust property and protecting the interest of the beneficiaries. It can be seen the trustees' duties became more specific by virtue of statutory provisions and almost all major duties and power of the trustees are now enshrined in the statutes (Trustee Act 1925, Trusts of Land and Appointment of Trustees Act 1996, Trustee Act 2000). The Trustees have always had a duty to invest the trust funds to provide an income for beneficiaries and to maintain or, indeed, increase the value of the trust (Cowan $v$ Scargill [1984] 2 All ER 750). In other word it can be define as the trustees' power of investment. The term investment has not been defined by statute but the Oxford English Dictionary meaning of investment was accepted in Re Wragg [1919] 2 Ch 55 at 64 as 'to employ money in the purchase of anything from which interest or profit is expected'.

The 'old law' as in section1 of the Trustee Act 1925 restricted trustees' powers of investment to safe such as stocks and mortgages on land. Buying land itself was forbidden as, historically, property prices have gone down as much they have gone up.( Re Power [1947] 2 All ER 282). Though the Trustee Investment Act 1961 extended the trustees power of investment in shares but still the investment power was restricted, in order to protect the beneficiaries from the trustee losing the trust fund in risky investment. Thus, after following the Law Commission No 260 (1999) report on Trustees Power and Duties the Trustee Act 2000 was enacted in 2000. The biggest changes affecting the area of the administration of trust were brought in by the Trustee Act 2000.

\section{Trustees' Power, Duties and Investments under New Statute}

The Trustee Act 2000 introduced the modern investment power for the trustees which broke with the past by freeing the trustees from any restriction on the kind of investments that they could made. (Panesar, S. 2001, p.28). But, the problem arose in the context of ethical investment because some private persons prefer not to invest in industries of which they morally disapprove such as gambling, alcohol or even newspapers. Therefore this issue reached before the court for interpretation that the duty of trustees is to make money for their beneficiaries, so could trustees adopt an ethical investment policy or not. In Cowan v Scargill [1985] Ch 270, the principle was established that trustees cannot make investment decision on political or 'moral' grounds but must consider the financial interests of the beneficiaries as paramount. In Harries v The Church Commissioner for England [1992] 1 WLR 1241, regarding ethical investment Nicholls VC said: "Trustees may, if they wish, accommodate the views of those who consider that on moral grounds a particular investment would be in conflict with the objects of the charity, so long as the trustees are satisfied that course would not involve a risk of significant financial detriment" (Harries v The Church Commissioner for England [1992] 1 WLR 1241 at 1247). Thus the case law suggests that ethical investment is legal as long as the profit motive is not neglected. However, it is important to mention here that the Trustee Act 2000 upholds the settlor's wishes in a trust instrument to secure certain ethical investments or avoid others (Trustee Act 2000, s. 6). These wishes must be reflected in any policy statement if the trustees delegate their investment power.

Section 1 of the Trustee Act 2000 imposes a statutory duty of care upon trustees concerning investment of trust property and associated activities. Section 1 (1) of the Trustee Act 2000 lays down that the trustees have a duty of care to act reasonably, having regard to any special knowledge and experience possessed or held out by them personally or in the course of their business or profession (Mohamed Ramjohn, 2013, p.158). Section 1(1) (b) of the Trustee Act is based on earlier case law which recognised that trustees would have a higher duty of care if they were professional trustees who charged for their service. In Bartlett v Barclays Bank Trust Company Limited [1980] Ch 515, Lord Brightman said: "I am of the opinion that a higher duty of cares is plainly due from someone like a trust corporation which carries on a specialised business of trust management"(Bartlett v Barclays Bank Trust Company Limited [1980] Ch 515 at 534). So, the professional trustees owe a higher duty of care. In accordance with schedule 1 of the Trustee Act 2000 the statutory duty of care arises in respect of investment powers as well as arrangements to delegate functions to agent, nominees and custodians, and the review of their action (Panesar, S., 2001, p.29). In addition the duty arises in respect of power to insure the trust property. Sections 4 and 5 provide trustees with guidance on how to manage their investments. In exercising any power of investment, whether under the Trustee Act or otherwise, a trustee must have regard to the standard investment criteria, and must from time to time review the investment of the trusts and consider whether having regard to such criteria, they should be varied (Trustee Act 2000, ss. 4 (1), (2)). 
In choosing investment under s 4 (3), trustee must have regard to the 'standard investment criteria' of suitability and the need for diversification. The suitability means it is the duty of the trustee to consider whether shares in a particular company are appropriate for the trust and the diversification reflects the Trustee Act 2000's adoption of the 'modern portfolio theory' set out in the first instance decision of Nestle $v$ National Westminster Bank PIc [1993] 1 WLR 1260 by Hoffman J as : "Modern trustees acting within their investment powers are entitled to be judged by the standards of current portfolio theory, which emphasises the risk level of the entire portfolio rather than the risk attaching to each investment taken in isolation an investment which in isolation is too risky and therefore in breach of trust may be justified when held in conjunction with other investments"(Nigel A. Clayton, 1988, p. 284-286). This encourages trustees to formulate an investment strategy that balances riskier investments which could bring greater returns) with more secure investments (which will produce lower returns but expose the trust fund to less risk (Lord Nicholls, 1995, p.71). The trustees should take and consider 'proper advice' from someone reasonably believed to be qualified by his own ability in and practical experience of financial and other matter whatever considering or reviewing their investments (Trustee Act 2000 , s. 5 (1), (4)). However, advice is not required if the trustee reasonably concludes that it is unnecessary or inappropriate to do so. The Trustee Act 2000 gives trustees the power to acquire freehold or leasehold land in the UK as (a) an investment, b) for occupying by beneficiary; or c) any other reason. Sections 11 and 15 of the Trustee Act 2000 lay down the trustees the power of delegation.

Section 11 outlines the role which can be collectively delegated by a trustee. However, the individual delegation of trustees' functions still governed by Trustee Act 1925. Section 15 of the trustee Act 2000 places special requirements on the delegation of asset management function. In addition, other statutory provisions permitting the trustees the delegation of discretions in many contexts. Section 22 of the Trustee Act 2000 states that trustees must keep their agents' act under review and if necessary, intervene and section 23 of the Trustee Act 2000 states that the trustees will be liable for the default of their agents if they have failed to satisfy the duty of care in appointing or review their agents. Sections 31 and 32 of the Trustee Act 1925 give statutory powers of maintenance and advancement. In addition such powers also derived from the express provisions of the trust instruments. The power of maintenance allows the trustees to use income from their interest to provide for the maintenance of a minor beneficiary (Re Turner's Will Trust [1936] Ch 15) and the power of advancement allows trustees, at their absolute discretion, to appoint part of beneficiaries' entitlement to the capital of the trust before it vests absolutely (Re Pauling's Settlement [1964] Ch 303). The duty of care under s.1 of the Trustee Act 2000 does not apply to these powers of maintenance and advancement.

\section{Power of Administration by the Trustees'}

Along with the powers and duties of investment, delegation, maintenance and advancement the trustees can exercise wide range of administrative power for the purpose of administering trust. The trustees have the administrative power to insure the property and pay the premium from the income or capital. In addition under s. 14 of the Trustee Act 1925 a trustee has a power to give valid receipt is a sufficient discharge to the person paying, transferring or delivering any money, securities or personal property or effects, exonerating recipient from being answerable for any loss or misapplication of the money. However, there is an exception in two situations where the receipt must be given by two trustees unless the trustee is a trust corporation: a) for the process of sale arising from land held under a trust; and b) for capital money arising under the Settled Land Act 1925. The trustees also hold administrative power in respect of compound liabilities. Under Section 15 of the Trustee Act 1925 in general gives wide powers to the trustees to compromise, compound, abandon, or settle any debt, account or claim relating to the testator, his estate, or the trust. Usually this power applies in the context of external dispute between trust estate and third parties but it not use in the context of external dispute between beneficiaries. In exercising the power under s. 15 of the Trustee Act 1925 the trustees will not be liable for loss cause by an act by done by them, if the trustees have used their statutory duty of care under section 1 of the Trustee Act 2000 in the exercise of section 15 Trustee Act 1925, as well as used their own discretion in deciding what to do and have not failed to consider the matter. Of course they may apply to the court to sanction the compromise, if any doubt occurs.

\section{Rights of the Beneficiaries'}

At the heart of a trust lies the fact that, while the trustee may have legal title to the trust property, real entitlement rests with the beneficiaries. In Nestle v National Westminster Bank PIc [1993] 1 WLR 1260, the court confirms that the trustees have a duty to act even-handedly towards the different classes of beneficiary. When a beneficiary is entitled to an income from trust property, trustees have a duty to invest. This duty is predominantly dealt with by the reforms of the Trustees Act 
2000. As it is duty of the trustees to provide information to the beneficiary, it is also right of beneficiary to see the trust documenter. However, in Re Londonderry's Settlement[1965] Ch 918, the court said that beneficiaries had the right to see the 'trust documents', but the trustee were not obliged to give reasons for their decisions. In addition recent case law also suggests that a beneficiary might be entitled to this information, but it is not an automatic right (Re Murphy's Settlements [1998] 3 All ER 1; Schmidt v Rosewood Trust [2003] 3 All ER 76(PC); Breakspear v Ackland [2009] Ch 32). The case of Schmidt v Rosewood Trust [2003] 3 All ER 76(PC), signal a significant change in the context of discretionary trust that beneficiaries no longer have an automatic right to demand information. In addition, trustees are not obliged to give reasons to the beneficiaries or explain to them why they have taken particular decisions.(Re Beloved Wilkes Charity [1851] 3 Mac \& G 440). At one stage these issues give raise a circumstance of discussion whether the trustees' power and duties are imbalance between in managing assets and protecting the interest of the beneficiaries. Because, when the Trustee Bill was proceeding through parliament, there were attempts to amend it in order to give more protection to the beneficiaries (Clements, $R$ and Abass, A., 2011, p. 117). The attempts failed. The beneficiaries have limited right to information from the trustees and the trustees do not have to explain or justify their decisions to the beneficiaries. It is thought that it is best to allow the trustees to do their work without interference by the beneficiaries (Wilson $v$ Law Debenture Trust Corp plc [1995] 2 All ER 337).

\section{Conclusion}

In conclusion it can be said that the trustees are left to run the trust in the best interest of the beneficiaries. So the trustees must follow the terms of the trust, act exclusively in the interest of the trust and generally do their best for the beneficiaries. Of course a heavy burden rests on the trustees because they must not just do what the beneficiaries ask or parents tell them to do, but exercise their discretion reasonably and properly. If the trustees failed to work reasonably or properly in administrating the trust, then the trustees could be strictly liable for breaches of trust. The purpose of the statutory provision since the Trustee Act 1925 to the Trustee Act 2000 is to make the trustees' powers and duties more specific and flexible so that the trustees can play their role effectively and flexibly in the administration of the trust. Thus above discussion makes it eligible to say that law relating to modern trustees' power and duties have achieved a balance between managing the trust assets and protecting the interest of the beneficiaries.

\section{References/ Bibliography}

\section{Legislation}

Public Trustee Act 1906

Law of Property Act 1925

Trustee Act 1925

Trusts of Land and Appointment of Trustees Act 1996

Trustee Delegation Act 1999

Trustee Act 2000

\section{Cases}

Bartlett v Barclays Bank Trust Company Limited [1980] Ch 515

Bary v Ford [1896] AC 44

Breakspear v Ackland [2009] Ch 32

Bristol and West Building Society v Mathew [1998] EWCA Civ 533

Buttle v Sunders [1950] 2 All ER 193

Cowan v Scargill [1984] 2 All ER 750

Harries v The Church Commissioner for England [1992] 1 WLR 1241

Imageview Management $v$ Jack [2009] 2 All ER 666

Learoyd $v$ Whitely (1886)LR 33 ChD 347

Luke v South Kensington Hotel Co (1879) 11 Ch D 121

Nestle v National Westminster Bank PIc 1993] 1 WLR 1260

Pilkington v IRC [1964] AC 612.

Re Beloved Wilkes Charity (1851) 3 Mac \& G 440

Re Londonderry's Settlement [1965] Ch 918

Re Murphy's Settlements [1998] 3 All ER 1

Re Pauling's Settlement [1964] Ch 303 
Re Power [1947] 2 All ER 282

Re Turner's Will Trust [1936] Ch 15

Re Wragg [1919] 2 Ch 55

Schmidt v Rosewood Trust [2003] 3 All ER 76(PC)

Wilson v Law Debenture Trust Corp plc [1995] 2 All ER 337

\section{Books}

Clements, R and Abass, A. (2011). Complete Equity and Trust-Text, Cases and Materials (2nd ed.). Oxford: Oxford University Press. Martin, Elizabeth A. (2009). Oxford Dictionary of Law (7th ed.).Oxford: Oxford University Press.

Moffat, G., Bean, G., and Probert, R.(2009). Trust Law, Text and Materials, (5th revised edn.). Cambridge: Cambridge University Press, p.421.

Mohamed Ramjohn.(2013). Beginning Equity and Trusts (First Publication,). London: Routledge. Journals

Gerwyn LI. H. Griffiths.(2005) 'Antipodean revelations? The beneficiary's right to information after "Rosewood"'. The Conveyancer and Property Lawyer, 39, 93-95.

Lord Nicholls.(1995). 'Trustees and their broader community: where duty, morality and ethics converge' Trusts Law International, $9,71$. Nigel A. Clayton(1988) 'The duty of a trustee to be prudent and fair' Journal of International Banking Law \& Regulation, 3, $284-286$.

Panesar, S. (2001) The Trustee Act 2000. Coventry Law Journal, 6, 28-37.

\section{Reports}

Law Commission No 260 (1999) Report on Trustees' Powers and Duties

\section{Website}

www.ligislation.gov.uk www.legisnexis.co.uk

www.westlaw.co.uk 